\title{
Examining the Emergence of Feminist Consciousness in the Select Fiction of Contemporary North East Women Writers
}

\author{
Adenuo Shirat Luikham \\ Assistant Professor, Department of English, Don Bosco College Kohima, Nagaland, India. \\ Email: adenuo@gmail.com.ORCID: oooo-0oo3-4273-3117.
}

\begin{abstract}
An interesting development in the literary world in India in the last few decades is the emergence of writings in English from the North East. This development is simultaneously accompanied with a growing interest in the region's writings and its people especially from mainland India. It is also noteworthy that many of the contemporary writers contributing to this nascent literary tradition are women. While the quality of any writing cannot be overshadowed or judged by gender, it is irrefutable that women write from a position where their gender often dictates their experiences. For contemporary women writers of the North East, their narratives, seated in the vehicle of fiction, become a revelation on the gendered experiences of women from the region whose issues, concerns and problems are often shrouded in a cloud of mystery and exoticized by the outside world. The paper seeks to examine the select fiction of women writers from the region and state that there is a discernible feminist consciousness that is emerging; identifying these feminist markers in their fiction allows the silenced voices of women to be heard and their growing boldness to claim a dignified existence in the midst of convoluted geo-politics that have irrevocably scarred the region.
\end{abstract}

Keywords: North East, Feminist Consciousness, Contemporary Women Writers, Fiction from the North East

\section{Introduction}

The North East region of India is a complex synthesis and amalgamation of heterogeneous population with multiethnic and multilingual cultures and this is clearly reflected in its literature. In contemporary times, there has been a sharp increase in publications from the region written in English especially in the genre of fiction (novels and short stories). A few reasons for this exponential growth can be attributed to: an increased interest in the region's varied cultures which also translates to an interest in its literature; increase in local publishing houses giving more opportunities to up and coming writers; and the aspect of viewing these writings as 'exotic' is at play and it piques the interests of a wider readership which transcends geographical boundaries.

It is should be noted that the umbrella term 'North East' and its application to literature from the region is contentious and problematic given that the coinage of the term was mainly for use in administrative purposes during the British rule which meant the importance of recognising

(C) AesthetixMS 2020. This Open Access article is published under a Creative Commons Attribution Non-Commercial 4.o International License (http://creativecommons.org/licenses/by-nc/4.o/), which permits non-commercial re-use, distribution, and reproduction in any medium, provided the original work is properly cited. For citation use the DOI. For commercial re-use, please contact editor@rupkatha.com. 
the cultural diversity of each of the eight states that make up the North East was not a primary concern for the administrators. As problematic as the term is, the tag, at present, works to the advantage of writers from the region, as it gives them the necessary spotlight especially since a literary tradition of works written in English is still in its nascent stage.

In the surge of literature from the North-East, many contemporary works are by women writers. This is a notable development and should be highlighted. Literature and narratives about the region have so far been presented from the viewpoint of the 'outsider' and is androcentric. Concurrently geo-political issues have ravaged the region since the formation of the states that comprises the North East; this has undoubtedly affected the different populations in each state. These issues have given rise to many concerns that have negatively impacted women and children, however, their experiences are silenced due to the androcentrism of the narratives that trickle out to the mainland. These contemporary North East women writers are therefore essential, if not, necessary mouth pieces that give voice to the experiences of women from all walks of life through their literary works.

In the select fiction of contemporary North East women writers that the paper has confined itself to, though these writers belong to different ethnic communities, they possess the commonality of shared experiences that are unique to the region. Some may even call it distinctly 'north eastern' and in articulating this distinctness through the lens of female experience, there is a discernible feminist consciousness that is emerging.

\section{Defining Feminist Consciousness in the Context of North East Women Writers}

The word 'feminist' in this context is used according to Toril Moi's definition of referring to "writing which takes a discernible anti-patriarchal and anti-sexist position," so the term 'feminist consciousness' is used to refer to a state of awareness of the self and the situation of belonging to a gender and the concerns that comes along with belonging to that gender (132).

Another definition for the term according to historian and feminist author Gerda Lerner in The Creation of Feminist Consciousness: From the Middle Ages to Eighteen-Seventy (1993) is:

(1)The awareness of women that they belong to a subordinate group and that, as members of such a group, they have suffered wrongs; (2) The recognition that their subordination is not natural, but societally determined; (3) The development of a sense of sisterhood; (4) the autonomous definition by women of their goals and strategies for changing their condition; and (5) the development of an alternate vision of the future. (274)

Women authors therefore invariably articulate the female experience because the very building blocks of their craft stems from the cognisance that they have been oppressed throughout history and continue to battle age-old systems of oppression. This validates the notion that Christiane Rochefort puts forth in "Privilege of Consciousness" where she writes that women's literature in itself should be considered as a "specific category, not because of biology, but because it is, in a sense, the literature of the colonized" (qtd. in "Feminist Criticism in the Wilderness", Showalter 339). Lerner also substantiates this statement by reiterating the significance of examining women's experiences in its own terms, she writes:

Women have been left out of history not because of the evil conspiracies of men in general or male historians in particular, but because we have considered history only in malecentred terms.... To rectify this, and to light up areas of historical darkness we must, for a time, focus on women-centred inquiry .... History must include an account of the female experience over time and include the development of feminist consciousness as an 

Women Writers

essential aspect of women's past. (qtd. in "Feminist Criticism in the Wilderness", Showalter 339-40)

Consequently, creativity becomes a vehicle and instrument by which women can emancipate themselves, intellectually, to a level from which they can climb out of the confines of the structures of patriarchal hierarchy (Feminist Consciousness, Lerner 275).

From the North East, with the exception of Assamese writer Indira Goswami, whose novels primarily focus on women's issues, gender relations, and the constraints of patriarchal societies on women, there is still a dearth of contemporary women writers who write exclusively on the woman question. That being said, since "writers necessarily articulate gendered experiences," all writing by women is invariably marked by gender and in the very act of writing, women writers from the region raise the consciousness of women themselves and give insights into female sensibilities (Ostriker 9).

In the North East, except the Khasi matrilineal system, majority of the ethnic communities follow a strongly patriarchal set up; instances of discrimination and oppression against women are not difficult to find. Women writers also inhabit this gendered space in their patriarchal societies and therefore their writings inevitably reflect the exploitation and marginalization they experience. The fiction of contemporary North East women writers are not overtly feminist but it reflects a self-awareness of being a woman in a patriarchal society. This awareness translates into the emergence of a feminist consciousness when examining the select texts which are discussed in the paper.

The following texts offer insights into the self-awareness of being female and consequently become a voice for the varied female experiences from the North East. Easterine Kire, who is from Nagaland, in her novel The Terrible Matriarchy, projects her female experience through the character Dieleno who faces gender discrimination. In Rebirth, by Jahnavi Barua, the protagonist has to confront many systematic prejudices and oppression as a woman, and through the character's experiences the writer assumes a voice that speaks out against patriarchy.

\section{Kire's A Terrible Matriarchy}

Kire's novel which was published in 2007 is a notable because it is one of the first texts to have addressed the issue of a Naga woman's place in a male dominated society. Kire's story is set in a Nagaland and delves into the life of a young girl, Dieleno, who is from the Angami tribe (one of the major tribes of the state). The Angamis, as are all the Naga tribes, are patriarchal and this system is maintained by means of strict adherence to customs, traditions and tribal dictums.

In A Terrible Matriarchy, the protagonist Dieleno whose name literally translates as 'errand girl' is the youngest of five children. She is made to go live with her strict disciplinarian grandmother who is determined to raise Dieleno into a 'good' Naga woman. The novel gives a realistic depiction of traditional Naga society, giving an insight into the dynamics of gender roles and discriminations faced by Naga women.

As mentioned, the patriarchal set up of Naga society means that Naga women experience lack of representation and are at a disadvantage politically, culturally and economically. Women are restricted from assuming seats of power in matters of policy-making (Ao, Benevolent Subordination" 125) and they do not inherit parental property i.e., ancestral property that has been passed down for generations from the male side (John Butler 305, 308). Societal expectations also mean that a woman is considered to be good if she is obedient and submissive; and she is expected to "perform the role of wife, mother, child bearer, food producer and household 
manager" ("Gender Equality"). Her identity is one that is constructed by dutiful conformity to a culture and tradition where the male wields absolute authority over his household and its matters. The men hold the crux of power in Naga society because it is based on a tradition of warrior values where the men have been traditionally given the role of protector and defender of the village considering that periodic raids within neighbouring villages occurred frequently. Hostilities between different clans, villages and tribes known as 'blood feuds' were a constant threat in the past and this led to men to "assume superior status in the male-female dichotomy" (Mills 302; Johnstone 313; Ao, "Benevolent Subordination" 126). Practical considerations, therefore, evolved into a situation where Naga women became excluded from assuming power in decisionmaking both in private and public matters.

Legalized by customs and traditions, the idea of the 'self' for Naga women is constructed with man as the absolute and woman as the other. On this, Temsula Ao, a pioneering poet and writer belonging to the first generation of Naga writers, notes that: "The socially constructed self of the [Naga] woman in the past was so thoroughly subordinated to the male that in time she too accepted it as the definition of her ontological selfhood" ("Benevolent Subordination” 129).

Given this place of a woman's position in Naga society, A Terrible Matriarchy becomes a text of the author's own experiences in the socio-cultural life of the Angami tribal society, and on a larger scale, the story can also be read as a representative of the discriminations that women experience in a male dominated society.

In the novel, Dieleno is severely discriminated by her own grandmother who treats her like a helper. The grandmother herself is a victim or can be seen as a product of the demands of the 'eternal feminine' that is expected of women in patriarchy. When the grandmother is empowered after she has fulfilled her roles as wife and mother according to what patriarchy dictates; she is conferred an auxiliary power which she exercises over her own family - especially the younger men and the female dependents under her care. It is interesting how the perpetuator of gender disparity is exercised by a female figure.

This 'feminist consciousness' in Kire is starkly aware of the discriminations and inequalities that her sex experiences and this is portrayed by showing at many instances in the novel where the young Dieleno is treated differently by her grandmother because she is female. This awareness of her gender's mistreatment and that it is to be a pervasive theme is introduced early on in the novel with the poignant opening lines:

My Grandmother didn't like me. I knew this when I was four and half .... "What meat do you want?" she simpered sweetly, as she ladled out gravy and meat. I quickly piped up, "I want the leg, Grandmother, give me the leg."

"I wasn't asking you, silly girl" ... "That portion is always for boys. Girls must eat other portions." (Kire 1)

Education for girls, specifically for Dieleno is another point of contention in the novel. For the grandmother, there was no value in girls getting formal education as long as they learned the skills of running a house. Though Dieleno faces opposition in many aspects due to her grandmother's deeply ingrained ideas of a woman's role and value, she manages to finish her studies successfully towards the end of the story. This accomplishment of the protagonist in the novel can be read as Kire's own assertion of her beliefs that a girl-child deserves as much opportunities as the male-child in Naga society. 
Kire's novel is not overtly feminist but it certainly contains overtones that acknowledge the gender inequalities and discriminations that women face in Naga society. Kire's own experiences of growing up in a traditional patriarchal Angami society gave her the inspiration to create Dieleno as a representative figure of the challenges that woman Naga women face.

\section{Barua's Rebirth}

Jahnavi Barua is an Assamese writer whose novel Rebirth was published in 2010. She is also the author of the critically acclaimed collection of short stories Next Door which was published in 2008.

Rebirth is the story of a young woman from Assam who settles down in Bangalore after her marriage to Ranjit (Ron). Kaberi's days are spent in housekeeping and reminiscing about her life in Assam. She also experiences difficulties assimilating into the corporate culture that her husband thrives in. The novel begins at a critical juncture when Ron announces that he is leaving Kaberi for another woman and at the same time she discovers that she is pregnant. This crisis in her life leads to a 'rebirth' as the title indicates.

Kaberi is a soft-spoken, reserved and timid woman who has married according to her parents' choice. She has been an obedient daughter and wife who display an incredible passiveness and acceptance of the roles that are expected of her. Kaberi's life revolves around Ron and her identity comes from being his wife. Kaberi appears to be passive even when Ron is verbally and physically aggressive. Her pacifist approach can be viewed as a "conditioning" that Kate Millet talks about in her Sexual Politics (1970) where she illuminates on how the socilaisation of the sexes in patriarchal polities allows the conditioning of "passivity, ignorance, docility and ineffectuality ..." into women (26).

Barua as a writer allows the narrative of Rebirth to bring to light through her nuanced storytelling the many psychological barriers that women encase themselves in. The passivity of Kaberi becomes a critique on how women are raised and subjugated in order to become docile, submissive and accommodating beings; ignoring their right to find or assert an identity apart from the men in her life or apart from the roles that are expected of her.

Conscious and aware of her gender, Barua is also critical of the institution of marriage. Marriage in Rebirth is presented as an oppressive contract of obligations because Kaberi is pressured to fulfil her maternal destiny and failing to do so becomes less desirable in the eyes of her husband. She is seen as a 'walking womb' that can be easily discarded if she fails to become a mother. Kaberi's economic dependence on her husband put her in a pitiable state; even when she threatens to walk out of the marriage, Ron mocks her:

'Are you going to leave her?' ...

'No,' Ron says, 'I will not. I will move back here, but I will come and go.'

'That won't do,' I say, my voice stiff.

'What do you mean, won't do?' Ron raised an eyebrow but the sarcasm rolls easily over me.

'And what will you do, what can you do, if I don't leave her? Ron is mocking now.

'I will divorce you then,' I say calmly.

Ron is incredulous. 'Divorce! Divorce! And how will you survive? Haven't you grown used to all this?' He points around the room .... 
.... I have grown accustomed to all the comforts he had provided me .... (Barua 85)

From the following excerpt Barua articulates almost perfectly the oppressive nature of marriage. The 'feminist consciousness' in her sees marriage as an institution that exploits and oppresses women. This goes in line with Simone de Beauvior's formulation in The Second Sex (1949) where she elucidates on how historically marriage is made a necessity for the sexes but the reciprocity is not. A woman has no "equal dignity" in marriage while the man remains socially autonomous and even acknowledged for his role as "producer" (502). Even though the traditional form of marriage maybe undergoing changes in terms of theoretical rights where spouses may appear equal but "as long as the main retains economic responsibility for the couple, this is only an illusion" (589).

Barua also shows how the dependency and powerlessness of Kaberi is a blueprint of her parents' fraught relationship. The complex and difficult relationship that Kaberi has with her mother reveals the conditioning that she has imbibed into her own marriage by subconsciously mirroring and emulating behaviours she had seen in her mother. In Rebirth, Barua dwells on the mother-daughter relationship to give a possible explanation for Kaberi's passive nature.

Adrienne Rich describes the mother-daughter relationship as:

The cathexis between mother and daughter - essential, distorted, misused - is the great unwritten story. Probably there is nothing in human nature more resonant with charges than the flow of energy between two biologically alike bodies, one which had lain in amniotic bliss inside the other, one which has laboured to give birth to the other. (qtd. in Hirsch 200-201)

This experience in the mother's womb when it happens within the confines of the institution of patriarchy becomes a "female experience that is shaped by male expectations and structures" (201). The mother's experience is internalized at a conscious and subconscious level which appears to be more prominent in the female infant because mothers identify more strongly "seeing them as an extension of themselves" - where the mother projects upon her daughter her own ambivalence about being female in a patriarchal culture (Hirsch 206-07).

Barua is acutely aware of the concerns that come with being a woman and in her novel she takes a very sensitive approach in dealing with feminine burdens. This feminine sensibility in her also makes sure that power is regained through an intensely feminine experience - motherhood. In Rebirth, a new beginning for Kaberi comes through the form of motherhood. Though Kaberi is at her most vulnerable state, due to her pregnancy, it is in the realization that she is carrying new life within her, that she is able to break the cycle of fear and subjugation. Through motherhood, her demeanour begins to change gradually and she gains the courage to confront things that have held her back in her life.

\section{Why Women's Writings from the North East?}

A literary tradition of writings in English is undoubtedly emerging from the North East and the significant footprint of women writers is an encouraging development. In examining the select fiction of women writers through a feminist perspective there are indications of the emergence of a 'feminist consciousness' which is worthy of attention and significant for further critical studies. Women writers from the North East are addressing issues and concerns that are pertinent and 
through their fictional works they offer a glimpse into the lives of women in the region as heterogeneous as it may be. Virginia Woolf wrote in Women and Fiction that "a woman's book is not written as a man would write it," emphasizing that female experience presented in women's writing is valid and fundamentally different from writings by men, and this holds true for women writers from the North East as well. By the simple act of writing and articulating their experiences, women writers from the North East are becoming a crucial voice in the silenced space that they inhabit in a man's world.

\section{References}

Ao, Temsula. (2003). Benevolent Subordination: Social Status of Naga Women. In P. Gill (Ed.), The Peripheral Centre: Voices from India's Northeast (pp. 125-129). Delhi: Zubaan Books.

Barua, Jahnavi. (2010). Rebirth. Delhi: Penguin Books India.

Beauvior, Simone de. (2010). The Second Sex (C. Borde, S.M. Chevallier, Trans.) (pp. 502, 589). New York, NY: Vintage Books. (Original work published 1949).

Butler, John. (1969). Angami Marriage Customs Rough Notes on the Angami Nagas. In V. Elwin (Ed.), The Nagas in the Nineteenth Century (pp. 305, 308). Oxford: Oxford University Press.

Shijoh, Z. (2014, April 30). Gender Equality in Naga Society. Degree of Thought. Retrieved from http://degreeofthought.dottalks.in/gender-equality-in-naga-society-zhovelu/

Hirsch, Marianne. (1981, Autumn). Mothers and Daughters. Signs: Journal of Women in Culture and Society 7(1), pp. 201-207. JSTOR. Retrieved from http://www.jstor.org/stable/3173518

Johnstone, J. (1969). Johnstone on the Angamis: My Experiences in Manipur and the Naga Hills, 1896. In V. Elwin (Ed.), The Nagas in the Nineteenth Century (p. 313). Oxford: Oxford University Press.

Kire, Easterine. (2007). A Terrible Matriarchy. Delhi: Zubaan Books.

Lerner, Gerder.(1993). The Creation of Feminist Consciousness: From the Middle Ages to Eighteen-Seventy (pp. 274-275). New York, NY: Oxford University Press. Retrieved from https://all-med.net/pdf/thecreation-of-feminist-consciousness/pdf

Millett, Kate. (1970, 2000). Sexual Politics (p. 26). Champaign, IL: University of Illinois Press.

Mills, Moffatt. Angami Life and Custom: Report on the Province of Assam, 1854. In V. Elwin (Ed.), The Nagas in the Nineteenth Century (p. 302). Oxford: Oxford University Press.

Ostriker, Alicia S. (1986). Stealing the Language: The Emergence of Women's Poetry in America (p. 9). Boston, MA: Beacon Press.

Showalter, Elaine. (1988). Feminist Criticism in the Wilderness. In D. Lodge (Ed.), Modern Criticism and Theory: A Reader (pp. 339-340). London, England: Pearson Education and Dorling Kindersley Publishing.

Adenuo Shirat Luikham is an educator from Kohima. She holds a PhD in English Literature from The English and Foreign Languages University, Hyderabad. She is the author of a collection of poems titled Luna. Bisous. Poesy published in 2019. A painter and an illustrator, she derives inspiration from the natural beauty of her home state, Nagaland, India. Her research interests include women narratives and writings in English from the North East. 